\title{
ANALIZA WYPŁACALNOŚCI ZAKŁADÓW UBEZPIECZEŃ W SOLVENCY II NA PRZYKŁADZIE WYBRANYCH UBEZPIECZYCIELI
}

\section{WPROWADZENIE}

Współczesny rynek ubezpieczeń gospodarczych charakteryzuje się dynamicznym rozwojem usług opierajacych się na nowych technologiach i zmieniających się kanałach dystrybucji. Znajduje się on w okresie przełomowych zmian obejmujących m.in. zasady prowadzenia działalności ubezpieczeniowej, zasady sprawowania nadzoru nad instytucjami ubezpieczeniowymi oraz zasady ochrony konsumenta usług ubezpieczeniowych. Artykuł jest próba prezentacji zasad wypłacalności zakładów ubezpieczeń w kontekście zmian regulacji prawnych dotyczących rynku ubezpieczeń gospodarczych. Debata nad koniecznością zmiany standardów wypłacalności zakładów ubezpieczeń w Unii Europejskiej toczyła się przez ponad 20 lat. W tym czasie powstały liczne prace naukowe oraz raporty firm konsultingowych wskazujące na pozytywne aspekty systemu wypłacalności opartego na kapitale ważonym ryzykiem. Efektem końcowym wieloletnich badań była dyrektywa Parlamentu Europejskiego i Rady 2009/138/WE z 25 listopada 2009 r. w sprawie podejmowania i prowadzenia działalności ubezpieczeniowej i reasekuracyjnej (Solvency II). Jest to obecnie najważniejszy akt prawny regulujący rynek ubezpieczeń gospodarczych w Unii Europejskiej.

Głównym celem niniejszego artykułu jest analiza wypłacalności wybranej grupy zakładów ubezpieczeń w systemie prawnym uregulowanym dyrektywa Solvency II. Omówiono także podstawowe zagadnienia związane z pojęciem wypłacalności zakładów ubezpieczeń, uregulowaniem tych kwestii w prawodawstwie oraz dokonano ogólnej charakterystyki wymagań stawianych zakładom ubezpieczeń w reżimie Solvency II.

Analizie poddano 10 polskich zakładów ubezpieczeń, działających na podstawie przepisów ustawy z 11 września 2015 r. o działalności ubezpieczeniowej i reasekuracyjnej. Przedmiotem analizy sa zagadnienia związane z wypłacalnością zakładów ubezpieczeń w kontekście implementacji dyrektywy Solvency II. Pominięto kwestie dotyczace rezerw techniczno-ubezpieczeniowych i działalności lokacyjnej zakładów ubezpieczeń. W badaniu uwzględniono jedynie wyniki osiagnięte przez zakłady ubezpieczeń w 2016, gdyż dopiero w maju 2017 r. pierwszy raz opublikowane zostały sprawozdania o wypłacalności i kondycji finansowej. Podstawową metodą badawczą jest analiza danych za- 
wartych w tych sprawozdaniach. W artykule odwołano się do literatury przedmiotu podejmującej problematykę wypłacalności zakładów ubezpieczeń oraz gospodarki finansowej zakładu ubezpieczeń.

\section{SYSTEM SOLVENCY II I JEGO WPROWADZENIE DO PRAWA POLSKIEGO}

Pojęcie wypłacalności zakładów ubezpieczeń utożsamiane jest w dyrektywach Unii Europejskiej z pewnym buforem bezpieczeństwa, rozumianym jako wartość aktywów wolnych od zobowiązań z tytułu świadczeń i odszkodowań, czyli różnicy pomiędzy kontrolowanym aktywami a całościa zobowiazań ubezpieczyciela ${ }^{1}$. Pojęciem symetrycznym do pojęcia wypłacalności jest pojęcie niewypłacalności, czyli stwierdzony prawomocnie przez uprawniony organ (nadzór ubezpieczeniowy, sąd) stan braku zdolności zakładu ubezpieczeń do wywiązywania się ze swoich zobowiązań wynikających z zawartych umów ubezpieczenia ${ }^{2}$. Samo pojęcie wypłacalności zakładów ubezpieczeń jest dosyć trudne do zdefiniowania i w związku z tym nie jest łatwo o jednoznaczne stwierdzenie, kiedy ubezpieczyciel przestaje być wypłacalny ${ }^{3}$.

W toku ewolucji systemów wypłacalności wykształciły się dwa podstawowe kierunki rozwoju systemów finansowych mających na celu zapewnienie bezpieczeństwa finansowego i wypłacalności ubezpieczycieli. W ramach pierwszego podejścia wykształcono pojęcie marginesu wypłacalności, obliczanego na podstawie przeszłych obserwacji dotyczących wielkości zebranych składek lub wielkości wypłacanych odszkodowań. Margines wypłacalności (Solvency I) i zasady jego kalkulacji zostały określone w ustawie z 23 maja 2003 r. o działalności ubezpieczeniowej i obowiązywały do czasu wprowadzenia dyrektywy Solvency II ustawą z 11 września 2015 r., która weszła w życie 1 stycznia 2016. Z kolei drugie podejście, czyli koncepcja kapitału ważonego ryzykiem, uwzględnia realne ryzyko prowadzonej działalności ubezpieczeniowej. Zakłady ubezpieczeń są zobligowane do identyfikowania różnych rodzajów ryzyka, na jakie będą narażone w przyszłości. Każdemu rodzajowi ryzyka zostaje następnie przypisana minimalna kwota kapitału własnego, który będzie niezbędny do zachowania bezpieczeństwa finansowego zakładów ubezpieczeń.

Nadrzędnym celem unijnej dyrektywy były standaryzacja i reorganizacja zasad prowadzenia działalności ubezpieczeniowej w krajach UE. Głównym zadaniem systemu Solvency II jest rozszerzenie zakresu nadzoru i wymogów

${ }^{1}$ M. Lament, Zarzqdzanie finansami zaktadów ubezpieczeń, w: M. Iwanicz-Drozdowska (red.), Ubezpieczenia, Warszawa 2013, s. 113.

${ }^{2}$ W. Bijak, Praktyczne metody badania niewyptacalności zakładów ubezpieczeń, Warszawa 2009, s. 15.

${ }^{3}$ Szerzej na temat definiowania wypłacalności zakładów ubezpieczeń zob. m.in. J. Lisowski, Specyfika gospodarki finansowej ubezpieczycieli kredytu kupieckiego w Polsce, Poznań 2010, s. $81-82$ i $333-335$. 
wypłacalności również na proces zarządzania zakładem ubezpieczeń, w szczególności w zakresie zarządzania ryzykiem i kontroli wewnętrznej ${ }^{4}$. Dyrektywa Solvency II zastapiła trzynaście odrębnie funkcjonujących dyrektyw ubezpieczeniowych i reasekuracyjnych ${ }^{5}$. Najważniejszym zagadnieniem w niej uregulowanym jest harmonizacja systemów wypłacalności zakładów ubezpieczeń i reasekuracji prowadzących działalność na terytorium Unii Europejskiej. Przełomowa reformą w systemie wypłacalności zakładów ubezpieczeń jest powiazzanie wymogów kapitałowych z faktycznie występującym całkowitym ryzykiem działalności. Szacowanie całkowitego ryzyka działalności obejmuje parametry jakościowe, ilościowe oraz przejrzystość prowadzonej działalności. Dyrektywa Solvency II skłania zakłady ubezpieczeń do prowadzenia efektywnej i skutecznej oceny oraz pomiaru ryzyka związanego z wykonywana działalnościa, a także do jak najbardziej efektywnego zarządzania tym ryzykiem.

Struktura systemu wypłacalności w dyrektywie Solvency II została ujęta $\mathrm{w}$ trzech filarach. W ramach pierwszego filaru ustawodawca wprowadził regulacje w zakresie wymogów kapitałowych (wymogi ilościowe) zakładów ubezpieczeń. Oprócz nowych zasad obliczania minimalnych wymagań kapitałowych w dyrektywie określono m.in. sposoby wyceny aktywów i pasywów dla celów wypłacalności, zasady tworzenia rezerw techniczno-ubezpieczeniowych dla celów wypłacalności oraz klasyfikacji środków własnych zakładów ubezpieczeń. Drugi filar dotyczy regulacji w zakresie procesu analizy nadzorczej. Celem tego filaru jest standaryzacja procesu kontroli wewnętrznej ubezpieczycieli, poprawa efektywności w obszarach zarządzania ryzykiem dostosowanych do charakteru działalności danego zakładu ubezpieczeń oraz zwiększenie kompetencji i odpowiedzialności zakładu ubezpieczeń w zakresie zadań związanych z szacowaniem poziomu ryzyka całkowitego. W ramach drugiego filaru mieści się również zasada „ostrożnego inwestora”, dotycząca sposobu lokowania środków przez zakłady ubezpieczeń. Trzeci filar odnosi się do obowiązków informacyjnych zakładów ubezpieczeń wobec innych uczestników rynku, w wyniku których zakład ubezpieczeń ma stać się transparentną instytucją finansową. W tym celu dyrektywa zobowiązuje zakłady ubezpieczeń do przestrzegania jednolitych wymagań dotyczących przejrzystości działalności podejmowanej przez ubezpieczycieli - wprowadza wysokie standardy raportowania i udostępniania opinii publicznej informacji odnośnie do osiagniętych wyników finansowych. Przejrzyście prowadzona działalność zakładów ubezpieczeń ma za zadanie dostarczyć użyteczne informacje inwestorom, konkurentom oraz przede wszystkim ubezpieczonym. Zakłady ubezpieczeń powinny w głównej mierze zwrócić uwagę na dwa rodzaje prezentowanych informacji6:

- informacje dotyczące sytuacji finansowej zakładów ubezpieczeń skierowane głównie do inwestorów, analityków i obserwatorów rynku finansowego,

- informacje skierowane do ubezpieczonych, dotyczące np. ubezpieczeń z kapitałowym funduszem inwestycyjnym.

${ }^{4}$ W. Bijak, op. cit., s. 15.

${ }^{5}$ G. Grzeszczak, Implementacja dyrektywy Wyptacalność II - perspektywa prawa europejskiego, „Wiadomości Ubezpieczeniowe” 2015, nr 1, s. 3.

${ }^{6}$ M. Lament, op. cit., s. 118. 
Efektem wprowadzonych przez dyrektywę Solvency II trzech filarów zasad prowadzenia działalności ubezpieczeniowej jest umożliwienie oceny wiarygodności towarzystw ubezpieczeniowych przez beneficjentów ich usług.

\section{ARCHITEKTURA SYSTEMU SOLVENCY II}

Dyrektywa Solvency II oraz uchwalona na jej podstawie ustawa z 11 września 2015 r. o działalności ubezpieczeniowej i reasekuracyjnej wprowadziły do polskiego systemu ubezpieczeń gospodarczych nowe zasady ustalania progów ostrożnościowych zapewniających wypłacalność zakładom ubezpieczeń. Architektura systemu Solvency II wskazuje, że zapewnienie bezpieczeństwa funkcjonowania zakładu ubezpieczeń jest związane z posiadaniem nadwyżki wartości dopuszczonych środków własnych nad określonymi wymogami kapitałowymi. System ten, podobnie jak poprzedni, charakteryzuje się dwoma progami ostrożnościowymi regulującymi adekwatność kapitałową zakładów ubezpieczeń. Dolny próg to minimalny wymóg kapitałowy (MCR - minimal capital requirement), który stanowi niezbędny kapitał do prowadzenia działalności przez zakład ubezpieczeń. Drugim progiem ostrożnościowym jest kapitałowy wymóg wypłacalności (SCR - solvency capital requirement), którego głównym zadaniem jest pokrycie różnego rodzaju przyszłych prawdopodobnych strat związanych z prowadzoną działalnością ubezpieczeniowa. Dwa progi ostrożnościowe pełnią bardzo ważną funkcję w kontekście sprawowania nadzoru nad zakładami ubezpieczeń. Jeżeli kapitałowy wymóg wypłacalności będzie utrzymywany w wartości niższej niż pożądanej przez ustawodawcę, organ nadzoru będzie mógł podjąć działania mające na celu przywrócenie adekwatności kapitałowej, zanim kapitały własne zakładu ubezpieczeń obniżą się do poziomu minimalnego wymogu kapitałowego. Wymogi kapitałowe sa pokrywane przez dopuszczone środki własne. Dyrektywa Solvency II w analizie pokrycia wymogów kapitałowych aktywami wskazuje na istotę ryzyka danych klas aktywów. Pokrycie progów ostrożnościowych przez środki własne jest warunkiem koniecznym do zapewnienia bezpieczeństwa prowadzenia działalności ubezpieczeniowej, ale nie jest warunkiem wystarczającym. System Solvency II wymaga dostosowania jakości aktywów do określonych wymogów kapitałowych ${ }^{7}$. W systemie wypłacalności obowiązującym do 2016 r. wskazano, że dodatkowe wolne środki mają za zadanie pokryć przede wszystkim ryzyko ubezpieczeniowe, bez uwzględnienia innych rodzajów ryzyka, na które narażony jest zakład ubezpieczeń.

System Solvency II nawiąuje swoją budową do amerykańskich systemów wypłacalności opartych na kapitale ważonym ryzykiem oraz do rozwiązań bankowej umowy kapitałowej Bazylea $\mathrm{II}^{8}$. W tych systemach, przy obliczaniu wymogów kapitałowych i środków własnych na ich pokrycie, uwzględnione zostało całkowite faktycznie występujące ryzyko działalności instytucji finan-

${ }^{7}$ Ibidem.

${ }^{8}$ M. Cycoń, Finanse zakładów ubezpieczeń, w: W. Sułkowska (red.), Wspótczesne ubezpieczenia gospodarcze, Poznań 2013, s. 118. 
sowych. Kalibracja wymogów kapitałowych zakładów ubezpieczeń na podstawie kapitału ważonego ryzykiem ma za zadanie zwiększyć realność ochrony ubezpieczeniowej. Ponadto uzależnienie wysokości wymogów kapitałowych od skali ryzyka podejmowanego przez zakłady ubezpieczeń stwarza możliwości obniżenia tych wymogów przez zastosowanie odpowiednich technik ograniczenia ryzyka. W efekcie zakłady ubezpieczeń przez odpowiednie zarządzanie ryzykiem będą mogły obniżyć wymagania kapitałowe i tym samym zwiększyć rentowność kapitału własnego przez relatywny wzrost kapitałów obcych i efekt dźwigni finansowej ${ }^{9}$.

\section{Schemat 1}

Architektura systemu Solvency II

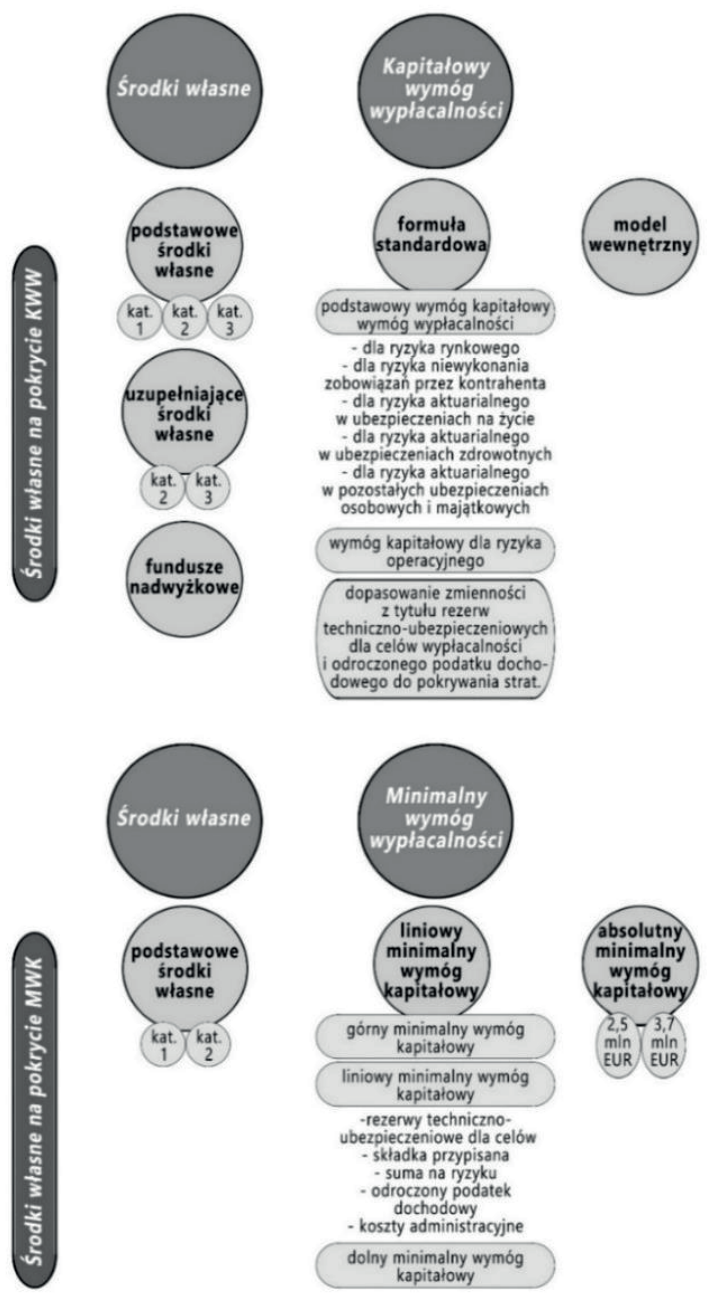

Źródło: opracowanie własne.

${ }^{9}$ M. Hamrol, Analiza finansowa przedsiębiorstwa, Poznań 2010, s. 99. 
System uregulowany dyrektywą Solvency II zapewnia jednolite rozwiąania w zakresie prowadzenia i zapewnienia bezpieczeństwa działalności zakładów ubezpieczeń na terytorium UE. Harmonizacji podlegają m.in. wyceny aktywów i pasywów, zasady obliczania wymogów kapitałowych i dopuszczonych środków własnych na ich pokrycie, zasady kalkulacji rezerw techniczno-ubezpieczeniowych i zasady prowadzenia polityki lokacyjnej ${ }^{10}$.

Z uwagi na ograniczona objętość artykułu bardziej szczegółowe rozważania na temat podstawowych wymogów kapitałowych stawianych zakładom ubezpieczeń nie będą przedmiotem tego opracowania ${ }^{11}$. Syntetyczną architekturę systemu Solvency II przedstawia schemat 1.

\section{SPRAWOZDAWCZOŚĆ ZAKŁADÓW UBEZPIECZEŃ W KONTEKŚCIE WPROWADZENIA DYREKTYWY SOLVENCY II}

Zakłady ubezpieczeń sa podmiotami zaliczanymi w poczet instytucji zaufania publicznego, które powinny przede wszystkim gwarantować realność ochrony ubezpieczeniowej. Z tego powodu ciążą na nich specyficzne obowiązki mające na celu zwiększenie zaufania do tych instytucji. Dyrektywa Solvency II oparła nowy system wypłacalności na trzech filarach. Ostatni z nich dotyczy obowiązków informacyjnych zakładów ubezpieczeń. Jej implementacja do poszczególnych systemów prawnych w państwach należacych do UE spowodowała powstanie zharmonizowanego systemu informacyjnego zakładów ubezpieczeń. Działalność ubezpieczycieli stała się w ten sposób bardziej transparentna, co może skutkować wzrostem zaufania do tych instytucji.

Zakłady ubezpieczeń w celu spełnienia swoich obowiązków informacyjnych zostały zobowiązane przez ustawodawcę do sporządzenia i ujawnienia co najmniej raz w roku sprawozdania o wypłacalności i kondycji finansowej. Ustawodawca określił ogólny zakres informacyjny oraz zasady sporządzania tego sprawozdania. Oba elementy zostały przedstawione w tabeli 1 .

Ustawodawca w ustawie o działalności ubezpieczeniowej i reasekuracyjnej wskazuje minimalną i obligatoryjną strukturę informacyjną sprawozdania o wypłacalności i kondycji finansowej zakładów ubezpieczeń. Sprawozdanie to powinno zawierać w szczególności opis:

- działalności i wyniku finansowego zakładu ubezpieczeń,

- systemu zarządzania wraz z oceną adekwatności do profilu ryzyka,

- poszczególnych kategorii ryzyka z uwzględnieniem ekspozycji, koncentracji, ograniczenia oraz wrażliwości na ryzyko,

- podstaw i metody wyceny aktywów i pasywów dla celów wypłacalności, wraz z wyjaśnieniem istotnych różnic pomiędzy wyceną dla celów rachunkowości a wyceną dla celów wypłacalności,

${ }^{10}$ A. Karmańska, Gospodarka finansowa zakładów ubezpieczeń gospodarczych, w: E. Wierzbicka (red.), Ubezpieczenia non-life, Warszawa 2011, s. 52.

${ }^{11}$ Wielu autorów o tym pisze, zob. m.in. T. Czerwińska, Regulacje mikroostrożnościowe sektora ubezpieczeń, w: eadem, K. Jajuga (red.), Ryzyko instytucji finansowych - Wspótczesne trendy i wyzwania Warszawa 2016, s. 230-285; eadem, Specyfika gospodarki finansowe zaktadów ubezpieczeń, w: W. Ronka-Chmielowiec (red.), Ubezpieczenia, Warszawa 2016, s. 201-204. 
- zarządzania kapitałem, uzupełniony o wielkość i strukturę środków własnych oraz ich jakość, a także wysokość kapitałowego wymogu wypłacalności oraz minimalnego wymogu kapitałowego ${ }^{12}$.

Zakłady ubezpieczeń zostały zobowiązane do ujawnieniu w sprawozdaniach o wypłacalności i kondycji finansowej wszystkich istotnych zdarzeń, które moga mieć wpływ na informacje zamieszczone w sprawozdaniu. Wśród takich zdarzeń należy wymienić stwierdzenie niezgodności z wymogami kapitałowymi.

Tabela 1

Zakres informacji oraz zasady doboru informacji przy sporządzaniu sprawozdań o wypłacalności i kondycji finansowej zakładu ubezpieczeń

\begin{tabular}{|l|l|}
\hline \multicolumn{1}{|c|}{$\begin{array}{c}\text { Zakres informacji ujawnianych } \\
\text { w sprawozdaniach o wypłacalności } \\
\text { i kondycji finansowej }\end{array}$} & $\begin{array}{c}\text { Zasady sporządzania sprawozdań } \\
\text { o wypłacalności i kondycji finansowej }\end{array}$ \\
\hline $\begin{array}{l}\text { Elementy jakościowe lub ilościowe lub odpo- } \\
\text { wiednie połączenie tych elementów }\end{array}$ & $\begin{array}{l}\text { Informacje zawarte w sprawozdaniu odzwier- } \\
\text { ciedlają charakter skalę i złożoność działalno- } \\
\text { ści danego zakładu, a w szczególności rodzaje } \\
\text { ryzyka właściwe dla jego działalności }\end{array}$ \\
\hline $\begin{array}{l}\text { Elementy odnoszące się do przeszłości, te- } \\
\text { raźniejszości lub przeszłości lub odpowiednie } \\
\text { połączenie tych elementów }\end{array}$ & $\begin{array}{l}\text { Informacje są dostępne, kompletne i spójne } \\
\text { w czasie }\end{array}$ \\
\hline $\begin{array}{l}\text { Dane pochodzace ze źródeł wewnętrznych lub } \\
\text { zewnętrznych lub odpowiednie połączenie } \\
\text { tych danych }\end{array}$ & $\begin{array}{l}\text { Informacje sa istotne, wiarygodne i zrozu- } \\
\text { miałe }\end{array}$ \\
\hline
\end{tabular}

Źródło: opracowanie własne.

Oprócz sprawozdań o wypłacalności i kondycji finansowej zakłady ubezpieczeń są oczywiście także zobowiązane sporządzić sprawozdanie finansowe, zgodnie z zasadami określonymi w ustawie z 29 września 1994 r. o rachunkowości, według załącznika nr 3, z uwagi jednak na tematykę tego opracowanie te kwestie nie będą tu analizowane.

\section{BADANIE WYPLACALNOŚCI I SYTUACJI FINANSOWEJ ZAKŁADÓW UBEZPIECZEŃ DZIAŁU II}

\section{Analizowane podmioty}

W badaniu zostanie opisana sytuacji finansowa zakładów ubezpieczeń prowadzących działalność ubezpieczeniową w obrębie pozostałych ubezpieczeń osobowych i ubezpieczeń majątkowych. W 2016 r. swoją działalność ubezpieczeniową w obrębie tego działu ubezpieczeń prowadziło 34 ubezpieczycieli. Do

12 Ustawa z 11 września 2015 r., art. 285. 
badania zostało wybranych 10 zakładów ubezpieczeń. Kryterium wyboru analizowanej grupy zakładów ubezpieczeń była wysokość składki zarobionej na udziale własnym w 2016 r. W badaniu pominięto Powszechny Zakład Ubezpieczeń SA, który w tymże roku posiadał największy udział w rynku ubezpieczeniowym pod względem składki zarobionej na udziale własnym i w znacznym stopniu zakłócałoby to możliwości porównań między poszczególnymi firmami. Do badania zostały wybrane następujace spółki:

- TUiR Allianz Polska SA (dalej jako: Allianz),

- Aviva TU Ogólnych SA (dalej jako: Aviva),

- AXA Ubezpieczenia TUiR SA (dalej jako: AXA),

- Compensa TU SA VIG (dalej jako: Compensa),

- STU Ergo Hestia SA (dalej jako: Ergo Hestia),

- TU Europa SA (dalej jako: Europa),

- Generali TU SA (dalej jako: Generali),

- Interrisk TU SA VIG (dalej jako: Interrisk),

- Uniqa TU SA (dalej jako: Uniqa),

- TUiR Warta SA (dalej jako: Warta).

Wybrane do badania zakłady ubezpieczeń kontrolowały w 2016 r. ponad $50 \%$ rynku ubezpieczeniowego pod względem składki zarobionej na udziale własnym.

Badanie obejmuje swoim zakresem opis sytuacji finansowej poszczególnych zakładów ubezpieczeń wchodzących w skład badanej grupy. Podstawowym źródłem informacji służacych do jego wykonania sa sprawozdania o wypłacalności i kondycji zakładów ubezpieczeń. Badanie dotyczy w szczególności oceny jakości i wysokości środków własnych kontrolowanych przez badanych ubezpieczycieli, dekompozycji podstawowego kapitałowego wymogu wypłacalności, kapitałowego wymogu wypłacalności oraz minimalnego wymogu kapitałowego, a także oceny stopnia pokrycia wymogów kapitałowych adekwatnymi środkami własnymi. Ze względu na fakt zmian prawnych w zakresie systemu wypłacalności zakładów ubezpieczeń niemożliwe jest dokonanie w pracy porównania wyników osiaganych przez zakłady ubezpieczeń w latach ubiegłych.

\section{Analiza środków własnych}

Środki własne zakładów ubezpieczeń prezentowanie sa w sprawozdaniu o wypłacalności i kondycji finansowej w pozycji E.1 - środki własne. Zakłady ubezpieczeń prezentują $\mathrm{w}$ tej pozycji zasady zarządzania środkami własnymi oraz ich uproszczona strukturę. Informacje dotyczące wysokości środków własnych badanych zakładów ubezpieczeń zostały zaprezentowane w tabeli 2 .

Wśród badanych zakładów ubezpieczeń najwięcej środków własnych posiadały Warta, Ergo Hestia, Allianz oraz Europa. Wartość środków własnych każdego z tych zakładów przekraczała 1 mld zł, a w przypadku Warty - ponad 2 mld zł. Wysoka wartość środków własnych kontrolowanych przez Wartę, Allianz, Ergo Hestię oraz Allianz wynika przede wszystkim z rozmiarów prowadzonej działalności przez te spółki mierzonej pod względem składki przypisanej na udziale własnym. Odmienna sytuacji wystapiła w Europie, w której środki własne dwukrotnie przewyższały składkę przypisaną na udziale własnym. 
Wskaźnik zabezpieczenia działalności wskazuje na relację pomiędzy składką przypisaną na udziale własnym a poziomem środków własnych stanowiących zabezpieczenie działalności ubezpieczeniowej. Informuje on o adekwatności wysokości środków własnych do rozmiarów prowadzonej działalności gospodarczej ${ }^{13}$. Wskaźnik ten należy do grupy nominant, co oznacza, że wartość tego wskaźnika powinna znajdować się w okolicach pewnej nominalnej wysokości ${ }^{14}$. Najniższy poziom tego wskaźnika wykazano w Towarzystwie Ubezpieczeń Europa i wynosił on jedynie 48,92\%. Taka sytuacja wskazuje, że środki własne tego zakładu ubezpieczeń są na relatywnie wysokim poziomie i nadmiernie zabezpieczają jego działalność. Stosunkowo wysoki poziom zabezpieczenia działalności środkami własnymi wykazał Interrisk. W tym przypadku wysokość składki przypisanej na udziale własnym była wartościowo zbliżona do sumy wartości środków własnych tego zakładu ubezpieczeń. Środki własne zakładów ubezpieczeń Compensa i Ergo Hestia były ponad dwukrotnie niższe od składki przypisanej na udziale własnym tych spółek, co oznacza, że wysokość tych środków własnych była relatywnie niska. Względnie wysoki poziom wskaźnika zabezpieczenia działalności ubezpieczeniowej odnotowano w przypadku zakładu ubezpieczeń Aviva (prawie 194\%). Z punktu widzenia analizy wypłacalności zakładów ubezpieczeń istotną kwestią jest ocena jakości środków własnych. Dane dotyczące rodzajów i jakości środków własnych zostały zaprezentowane w tabeli 2 .

Tabela 2

Wysokość środków własnych zakładów ubezpieczeń i wskaźnik stopnia zabezpieczenia działalności ubezpieczeniowej (w tys. zł)

\begin{tabular}{|l|c|c|c|}
\hline $\begin{array}{c}\text { Zakład } \\
\text { ubezpieczeń }\end{array}$ & Środki własne & $\begin{array}{c}\text { Składka przypisana } \\
\text { na udziale własnym }\end{array}$ & $\begin{array}{c}\text { Wskaźnik stopnia } \\
\text { zabezpieczenia } \\
\text { działalności } \\
\text { ubezpieczeniowej }\end{array}$ \\
\hline Allianz & $\mathbf{1 0 1 8 \mathbf { 6 7 0 }}$ & 1466505 & $143,96 \%$ \\
\hline Aviva & $\mathbf{2 3 5 \mathbf { 7 3 3 }}$ & 456660 & $193,72 \%$ \\
\hline AXA & $\mathbf{1 7 7} \mathbf{1 2 2}$ & 280448 & $158,34 \%$ \\
\hline Compensa & $\mathbf{4 4 2 \mathbf { 0 0 3 }}$ & 904377 & $204,61 \%$ \\
\hline Ergo Hestia & $\mathbf{1 6 1 9 \mathbf { 2 5 7 }}$ & 3386746 & $209,15 \%$ \\
\hline Europa & $\mathbf{1 0 1 3 \mathbf { 1 9 2 }}$ & 280949 & $48,92 \%$ \\
\hline Generali & $\mathbf{5 5 9 5 2 1}$ & 803832 & $143,66 \%$ \\
\hline Interrisk & $\mathbf{4 9 8} \mathbf{0 6 1}$ & 495673 & $99,52 \%$ \\
\hline Uniqa & $\mathbf{4 3 1 6 3 6}$ & 579071 & $134,16 \%$ \\
\hline Warta & $\mathbf{2} \mathbf{2 9 9} \mathbf{3 8 1}$ & 3851876 & $167,52 \%$ \\
\hline
\end{tabular}

Źródło: opracowanie własne.

${ }^{13}$ L. Gąsiorkiewicz, Analiza finansowa banków i zakładów ubezpieczeń, Warszawa 2016, s. 99.

14 A. Jędrzychowska, Ocena płynności i wypłacalności zakładów ubezpieczeń z polskiego ryn$k u$, „Wiadomości Ubezpieczeniowe” 2009, nr 4, s. 35. 
W 2016 r. żaden z badanych zakładów ubezpieczeń nie posiadał uzupełniających środków własnych. Na środki własne badanych zakładów ubezpieczeń składały się środki własne zaliczane do wszystkich kategorii jakościowych. Zdecydowanie największą grupę stanowiły środki własne zaliczane do kategorii 1, które stanowiły ponad 95\% środków własnych kontrolowanych przez analizowane zakłady ubezpieczeń. Wartość środków własnych zaliczanych do kategorii 2 i kategorii 3 stanowiła odpowiednio 4,43\% i 0,44\% wszystkich środków własnych badanych zakładów ubezpieczeń. W 2016 r. pięć spośród wszystkich badanych zakładów ubezpieczeń posiadało środki własne zaliczane wyłącznie do kategorii 1 . Na środki własne zaliczane do tej kategorii składały się głównie kapitały zakładowe, nadwyżka ze sprzedaży akcji powyżej ich wartości nominalnej oraz rezerwa uzgodnieniowa, obliczana jako nadwyżka aktywów nad zobowiązaniami dla celów wypłacalności powiększona o akcje własne oraz pomniejszona o przewidywane dywidendy, wypłaty i obciążenia.

Tabela 3

Jakość środków własnych zakładów ubezpieczeń (w tys. zł)

\begin{tabular}{|c|c|c|c|c|c|}
\hline \multirow{2}{*}{$\begin{array}{c}\text { Zakład } \\
\text { ubezpieczeń }\end{array}$} & \multirow{2}{*}{$\begin{array}{l}\text { Środki } \\
\text { własne }\end{array}$} & \multirow{2}{*}{$\begin{array}{c}\text { W tym uzu- } \\
\text { pełniające } \\
\text { środki } \\
\text { własne }\end{array}$} & \multicolumn{3}{|c|}{ W tym środki własne zaliczane do: } \\
\hline & & & Kategorii 1 & Kategorii 2 & Kategorii 3 \\
\hline Allianz & 1018670 & $\mathbf{0}$ & 1018670 & 0 & 0 \\
\hline Aviva & 235733 & $\mathbf{0}$ & 235733 & 0 & 0 \\
\hline AXA & 177122 & $\mathbf{0}$ & 177122 & 0 & 0 \\
\hline Compensa & 442003 & $\mathbf{0}$ & 410709 & 0 & 31294 \\
\hline Ergo Hestia & 1619257 & $\mathbf{0}$ & 1441709 & 177548 & \\
\hline Europa & 1013192 & $\mathbf{0}$ & 1013192 & 0 & 0 \\
\hline Generali & 559521 & $\mathbf{0}$ & 454279 & 99963 & 5279 \\
\hline Interrisk & 498061 & $\mathbf{0}$ & 475284 & 22777 & 0 \\
\hline Uniqa & 431636 & $\mathbf{0}$ & 364547 & 67089 & 0 \\
\hline Warta & 2299381 & 0 & 2299381 & 0 & 0 \\
\hline
\end{tabular}

Źródło: opracowanie własne.

W badanym roku Ergo Hestia, Generali, Interrisk oraz Uniqa posiadały środki własne zaliczane do kategorii 2, które stanowiły 10,96\%, 17,87\%, 4,57\% oraz $15,54 \%$ wszystkich środków własnych kontrolowanych przez te zakłady ubezpieczeń. $\mathrm{Na}$ środki własne zaliczane do kategorii 2 zakładu ubezpieczeń Generali składała się pożyczka podporządkowana udzielona przez spółkę Generali Życie TU SA, z kolei w przypadku Interrisk była to pożyczka udzielona przez większościowego akcjonariusza, którym jest spółka Vienna Insurence Group AG Wiener Versicherung Gruppe. Zakład ubezpieczeń Uniqa wskazał 
w sprawozdaniu o kondycji finansowej, że na środki własne kategorii 2 składało się zobowiązanie podporządkowane, z kolei Ergo Hestia wskazała w tej kategorii środków własnych pożyczkę wymagalną w 2025 r. Środki własne zaliczane do kategorii 3 posiadały jedynie dwa zakłady ubezpieczeń: Compensa i Generali. W przypadku Compensy środki te stanowiły 7,08\% wszystkich środków własnych i składała się na nie pożyczka podporzą dkowana o terminie spłaty w 2020 r. Wartość środków własnych zaliczanych do kategorii 3 zakładu ubezpieczeń Generali stanowiła mniej niż 1\% wszystkich środków własnych i wynikała przede wszystkim ze zmiany pozycji odroczonego podatku dochodowego w sprawozdaniu statutowym.

Wszystkie badane zakłady ubezpieczeń posiadały głównie środki własne o najlepszej jakości. Taka sytuacja sprawia, że mogą one praktycznie bez żadnych ograniczeń wykorzystać te środki na pokrycie swoich wymogów kapitałowych w celu spełnienia standardów wypłacalności narzuconych przez ustawodawcę w ustawie o działalności ubezpieczeniowej i reasekuracyjnej.

\section{Analiza kapitałowego wymogu wypłacalności}

Kapitałowy wymóg wypłacalności (SCR) jest prezentowany w sprawozdaniu o wypłacalności i kondycji finansowej zakładów ubezpieczeń w pozycji E2-kapitałowy wymóg wypłacalności i minimalny wymóg kapitałowy. W 2016 r. żaden z zakładów ubezpieczeń prowadzących działalności w Polsce nie uzyskał zgody Komisji Nadzoru Finansowego na obliczanie kapitałowego wymogu wypłacalności przy zastosowaniu pełnego lub częściowego modelu wewnętrznego. W efekcie moduły ryzyka wszystkich analizowanych zakładów ubezpieczeń zostały obliczone przy zastosowaniu formuły standardowej.

Udział poszczególnych modułów ryzyka w kalkulowaniu podstawowego wymogu wypłacalności został wskazany na wykresie 1 . Z danych zawartych na tym wykresie wynika, że w 2016 r. kluczowym ryzykiem wśród badanych zakładów ubezpieczeń było ryzyko ubezpieczeniowe w ubezpieczeniach majątkowych, co jest charakterystyczne dla zakładów ubezpieczeń prowadzących swoją działalności w zakresie ubezpieczeń działu II. Obliczony na podstawie tego modułu ryzyka podstawowy SCR stanowił prawie $65 \%$ całkowitego podstawowego SCR, bez uwzględnienia efektów dywersyfikacji. Drugim pod względem istotności modułem ryzyka było ryzyko rynkowe, które determinowało prawie $20 \%$ podstawowego SCR analizowanej grupy zakładów ubezpieczeń. Moduły ryzyka aktuarialnego w ubezpieczeniach zdrowotnych oraz niewykonania zobowiązań przez kontrahenta stanowiły odpowiednio 5,38\% oraz $8,54 \%$ podstawowego SCR w analizowanej grupie zakładów ubezpieczeń. Moduł ryzyka w ubezpieczeniach na życie miał marginalny wpływ na wysokość podstawowego SCR we wszystkich badanych zakładach ubezpieczeń.

W analizie modułów ryzyka poszczególnych zakładów ubezpieczeń zdecydowanie przeważał moduł ryzyka aktuarialnego w ubezpieczeniach nieżyciowych. Największy wpływ tego modułu ryzyka przy obliczaniu podstawowego kapitałowego wymogu wypłacalności odnotowano w zakładach ubezpieczeń Ergo Hestia, Avivia oraz Uniqa (ponad 70\% ogólnego ryzyka). Wysoki poziom 
ryzyka aktuarialnego w ubezpieczeniach majątkowych wynikał przede wszystkim z oszacowania podmodułu ryzyka składki i rezerw. Najniższy udział tego modułu ryzyka w profilach ryzyka zakładów ubezpieczeń odnotowano w zakładach ubezpieczeń AXA i Europa (nie przekraczał 50\%).

\section{Wykres 1}

Udział poszczególnych modułów ryzyka w tworzeniu podstawowego kapitałowego wymogu wypłacalności

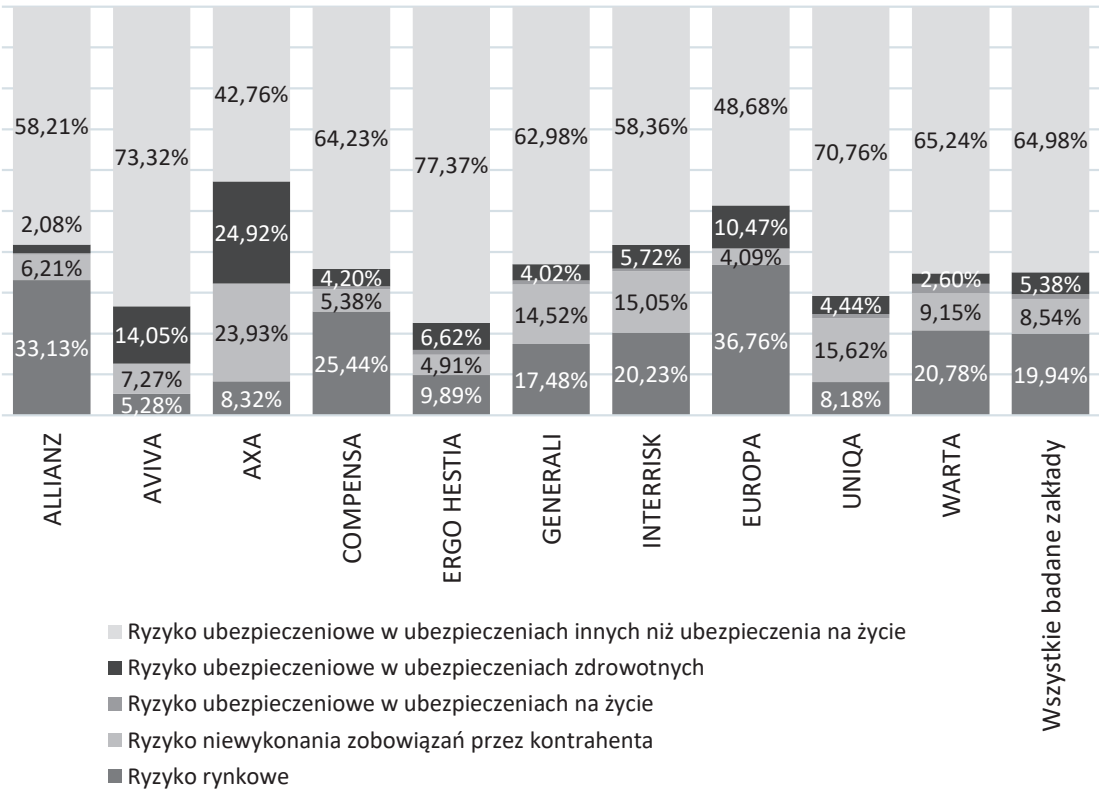

Źródło: opracowanie własne.

Ryzyko rynkowe miało znaczący wpływ na wysokość podstawowego SCR w zakładach ubezpieczeń Europa, Allianz oraz Compensa, w których determinowało ono odpowiednio $36,76 \%, 33,13 \%$ oraz $25,44 \%$ wymogów kapitałowych tych zakładów. Moduł ryzyka rynkowego miał marginalny udział w kształtowaniu SCR zakładów ubezpieczeń Aviva, AXA oraz Uniqa.

Ryzyko niewykonania zobowiązań przez kontrahenta stanowiło istotny moduł ryzyka dla zakładu AXA, który determinował ponad $20 \%$ wysokości podstawowego wymogu wypłacalności. Stosunkowo wysokie znaczenie tego modułu ryzyka w kalkulacji SCR wykazały także zakłady ubezpieczeń Generali, Interrisk oraz Uniqa. Moduł ryzyka w ubezpieczeniach zdrowotnych miał w większości zakładów niewielkie znaczenie przy kalibracji podstawowego kapitałowego wymogu wypłacalności. Odmienna sytuacja wystapiła w profilach ryzyka zakładów ubezpieczeń AXA, Aviva oraz Europa, w których ten moduł ryzyka determinował odpowiednio ponad $24 \%$, 14\% i 10\% wysokości podstawowego kapitałowego wymogu wypłacalności. 
Podstawowy kapitałowy wymóg wypłacalności obliczony na podstawie modułów ryzyka może zostać obniżony dzięki wykorzystaniu efektu dywersyfikacji. Jego występowanie jest konsekwencją sposobu szacowania SCR, polegajacym na agregacji wielu rodzajów ryzyka ubezpieczyciela, choć nie wszystkie z nich realizuja się w tym samym czasie. Powoduje to, że łączna wartość kapitału niezbędnego do zabezpieczenia się przed tymi ryzykami jest na ogół mniejsza (lub równa) od sumy kapitałów wymaganych do zabezpieczenia się przed każdym z nich z osobna ${ }^{15}$. Dane dotyczące efektu dywersyfikacji zostały zaprezentowane w tabeli 4. W 2016 r. wszystkie badane zakłady ubezpieczeń dzięki dywersyfikacji ryzyka pomiędzy poszczególnymi modułami, obniżyły swoje wymagania kapitałowe. Na efektach dywersyfikacji najwięcej zyskał zakład ubezpieczeń AXA, który zdołał obniżyć swoje wymagania kapitałowe o ponad 30\%. TU Europa dzięki efektom dywersyfikacji obniżyło swój podstawowy kapitałowy wymóg wypłacalności o $27,68 \%$. Ponad 20-procentowy efekt dywersyfikacji ryzyka wystapił w zakładach ubezpieczeń Allianz, Compensa, Generali, Interrisk oraz Warta.

\section{Tabela 4}

Efekt dywersyfikacji przy obliczaniu podstawowego kapitałowego wymogu wypłacalności (w tys. zł)

\begin{tabular}{|l|c|c|c|c|}
\cline { 2 - 5 } & $\begin{array}{c}\text { Podstawowy } \\
\text { kapitałowy } \\
\text { wymóg wypła- } \\
\text { calności bez } \\
\text { uwzględnienia } \\
\text { dywersyfikacji }\end{array}$ & Dywersyfikacja & $\begin{array}{c}\text { Dywersyfikacja } \\
\text { w ujęciu \% }\end{array}$ & $\begin{array}{c}\text { Podstawowy } \\
\text { kapitałowy } \\
\text { wymóg wypła- } \\
\text { calności }\end{array}$ \\
\hline Allianz & 867116 & -195095 & $-22,50 \%$ & 672021 \\
\hline Aviva & 177377 & -34492 & $-19,45 \%$ & 142885 \\
\hline AXA & 168427 & -51789 & $-30,75 \%$ & 116638 \\
\hline Compensa & 410894 & -89216 & $-21,71 \%$ & 321678 \\
\hline Ergo Hestia & 1528115 & -249423 & $-16,32 \%$ & 1278691 \\
\hline Europa & 591320 & -163689 & $-27,68 \%$ & 427630 \\
\hline Generali & 492518 & -105514 & $-21,42 \%$ & 387003 \\
\hline Interrisk & 370443 & -88075 & $-23,78 \%$ & 282369 \\
\hline Uniqa & 362194 & -62134 & $-17,15 \%$ & 300058 \\
\hline Warta & 1975800 & -416512 & $-21,08 \%$ & 1559288 \\
\hline
\end{tabular}

Źródło: opracowanie własne.

Zgodnie z wymaganiami stawianymi przez ustawodawcę badane zakłady ubezpieczeń, obliczając kapitałowy wymóg wypłacalności, uwzględniły ryzyko operacyjne oraz zdolność odroczonych podatków dochodowych do pokrywania

${ }_{15} \mathrm{~S}$. Wanat, Ocena efektu dywersyfikacji ryzyka $w$ Solvency II - aspekty metodyczny i praktyczny, „Wiadomości Ubezpieczeniowe” 2014, nr 3, s. 36. 
strat. Uwzględnienie tych dwóch czynników w większości przypadków powodowało obniżenie kapitałowego wymogu wypłacalności, ponieważ zdolność odroczonych podatków dochodowych do pokrywania strat przewyższała wartość kapitałowego wymogu wypłacalności oszacowanego dla ryzyka operacyjnego (tabela 5). Odwrotną zależność wykazały jedynie AXA i Uniqa, w których kapitałowy wymóg wypłacalności zwiększył się na skutek uwzględnienia ryzyka operacyjnego i zdolności odroczonych podatków dochodowych do pokrywania strat odpowiednio o 3363 tys. zł i 17520 tys. zł.

Tabela 5

Dekompozycja kapitałowego wymogu wypłacalności (w tys. zł)

\begin{tabular}{|c|c|c|c|c|}
\hline & $\begin{array}{l}\text { Podstawowy } \\
\text { kapitałowy } \\
\text { wymóg } \\
\text { wyplacalności }\end{array}$ & $\begin{array}{c}\text { Ryzyko } \\
\text { operacyjne }\end{array}$ & $\begin{array}{c}\text { Zdolność } \\
\text { odroczonych } \\
\text { podatków } \\
\text { dochodowych } \\
\text { do pokrywania } \\
\text { strat } \\
\end{array}$ & $\begin{array}{c}\text { Kapitałowy } \\
\text { wymóg } \\
\text { wypłacalności }\end{array}$ \\
\hline Allianz & 672021 & 53577 & -60322 & 665276 \\
\hline Aviva & 142885 & 12431 & -29510 & 125806 \\
\hline AXA & 116638 & 10610 & -7247 & 120001 \\
\hline Compensa & 321678 & 34806 & -67732 & 288752 \\
\hline Ergo Hestia & 1278691 & 117841 & -161744 & 1234788 \\
\hline Europa & 427630 & 16149 & -27068 & 416711 \\
\hline Generali & 387003 & 57460 & -84448 & 360015 \\
\hline Interrisk & 282369 & 26304 & -57727 & 250946 \\
\hline Uniqa & 300058 & 33707 & -16187 & 317578 \\
\hline Warta & 1559288 & 125022 & -291217 & 1393093 \\
\hline
\end{tabular}

Źródło: opracowanie własne.

\section{Analiza minimalnego wymogu kapitałowego}

Informacje dotyczące minimalnego wymogu kapitałowego zostały zawarte w części E2 sprawozdania o wypłacalności i kondycji finansowej zakładu ubezpieczeń. W tych sprawozdaniach zakłady ubezpieczeń wykazują liniowy minimalny wymóg kapitałowy jako sumę komponentów formuły liniowej dla zobowiązań ubezpieczeniowych i reasekuracyjnych z tytułu ubezpieczeń życiowych i z tytułu ubezpieczeń majątkowych. Komponent formuły liniowej dla zobowiązań z tytułu ubezpieczeń majątkowych miał zdecydowanie większy wpływ na wartość liniowego MCR. Wartość tego komponentu wynikała z wartości najlepszego oszacowania rezerw techniczno-ubezpieczeniowych oraz wartości 
składki przypisanej netto w okresie ostatnich 12 miesięcy z tytułu zawartych umów ubezpieczenia.

Na komponent dotyczący zobowiązań z tytułu zawartych ubezpieczeń na życie, oprócz najlepszego oszacowania i rezerw techniczno-ubezpieczeniowych, składała się całkowita suma na ryzyku netto reasekuracji i spółek celowych. Szczegółowe kwestie dotyczące obliczania liniowego minimalnego wymogu kapitałowego zostały w pracy pominięte. Wartości obu komponentów oraz wartość liniowego kapitałowego wymogu wypłacalności zostały zaprezentowane w tabeli 6 .

Wykres 2

Minimalny wymóg kapitałowy (w tys. zł)

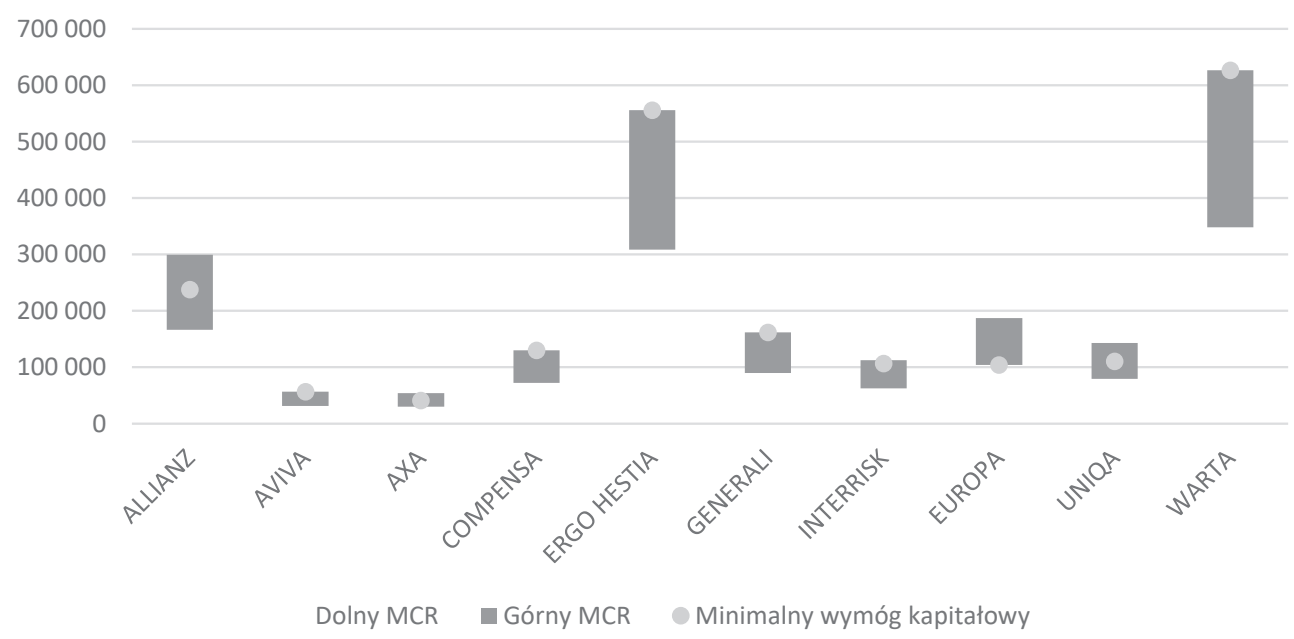

Źródło: opracowanie własne.

Wysokość minimalnego wymogu kapitałowego zależy także od wysokości kapitałowego wymogu wypłacalności. Zakłady ubezpieczeń w swoich sprawozdaniach o wypłacalności i kondycji finansowej prezentują górny MCR stanowiący $45 \%$ wartości SCR oraz dolny MCR, który odpowiada $25 \%$ wartości SCR. Na wykresie 2 przedstawiono dolną i górna granicę MCR oraz MCR każdego badanego zakładu ubezpieczeń. $\mathrm{Z}$ danych zawartych na wykresie 2 oraz w tabeli 6 wynika, że minimalny wymóg kapitałowy większości badanych zakładów ubezpieczeń znajdował się w okolicach górnej granicy MCR. Taka sytuacja zdarzyła się w zakładach ubezpieczeń Aviva, Compensa, Ergo Hestia, Generali oraz Warta. Liniowy MCR pokrywał się z MCR w zakładach ubezpieczeń Allianz, AXA, Interrisk i Uniqa. Z kolei liniowy MCR Europy był wyraźnie niższy od dolnego MCR oszacowanego dla tego zakładu ubezpieczeń. 


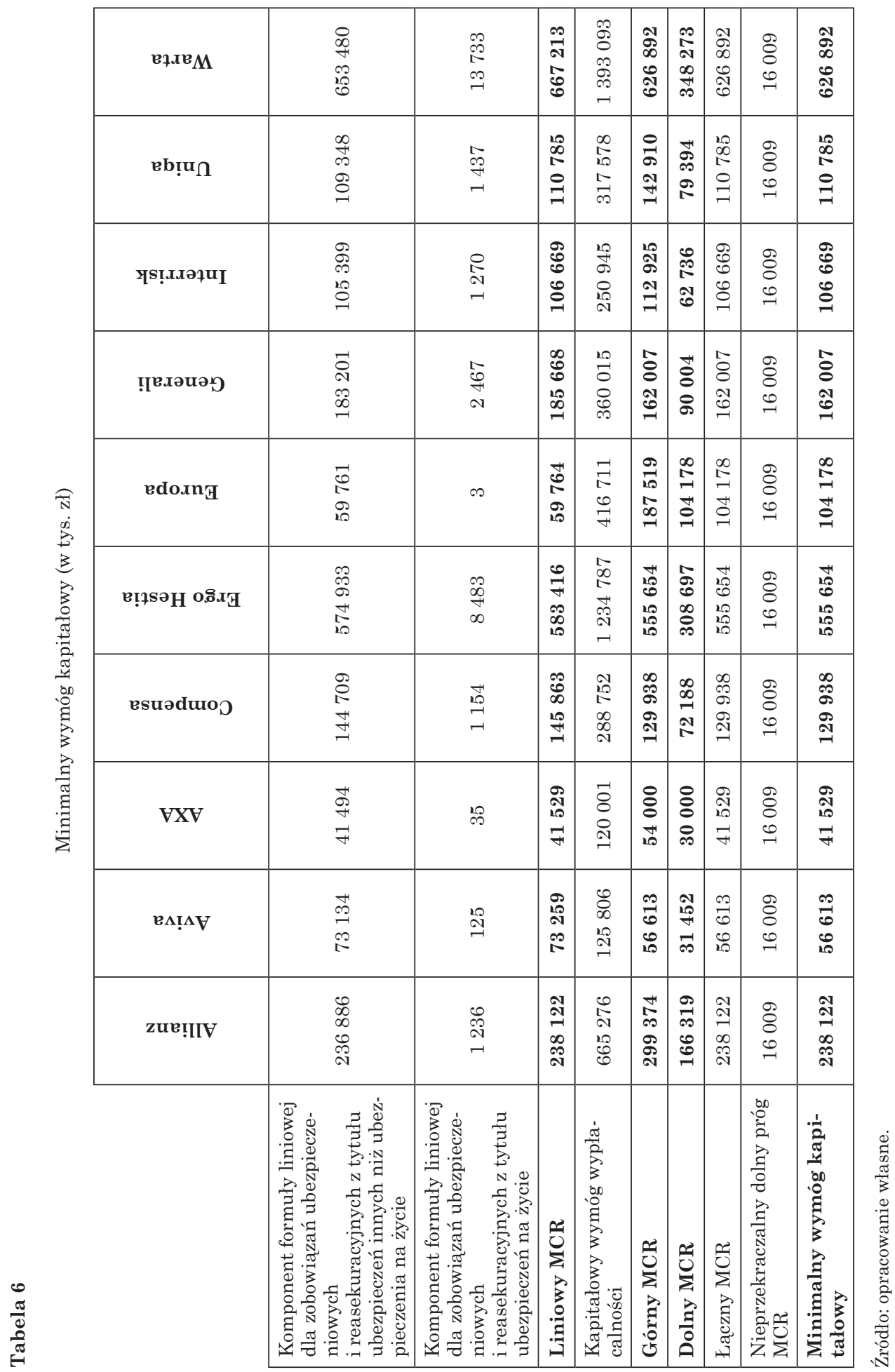




\begin{tabular}{|c|c|c|c|c|c|c|c|c|c|}
\hline \multirow{11}{*}{ 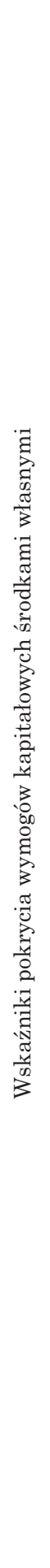 } & eq.xe $M$ & $\begin{array}{l}\vec{\infty} \\
\infty \\
\stackrel{2}{ } \\
\stackrel{N}{N} \\
\text { N }\end{array}$ & 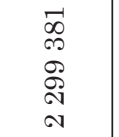 & 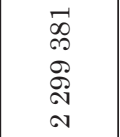 & 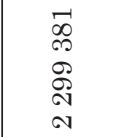 & 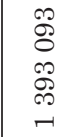 & 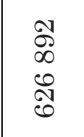 & $\begin{array}{l}\stackrel{0}{0} \\
0 \\
0 \\
10 \\
0 \\
-1\end{array}$ & $\begin{array}{l}\stackrel{0}{\circ} \\
\stackrel{0}{0} \\
\dot{0} \\
0 \\
0\end{array}$ \\
\hline & eb!̣u & $\begin{array}{l}\hat{\mathscr{O}} \\
\overrightarrow{0} \\
\vec{P} \\
\ddot{F}\end{array}$ & 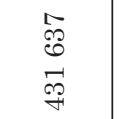 & $\begin{array}{l}\hat{0} \\
\tilde{0} \\
\vec{\sigma} \\
\stackrel{5}{+}\end{array}$ & $\begin{array}{l}\qquad 8 \\
\stackrel{0}{1} \\
0 \\
0 \\
0\end{array}$ & $\begin{array}{l}\infty \\
2 \\
10 \\
上 \\
\infty\end{array}$ & $\begin{array}{l}1 \\
\infty \\
亡 \\
0 \\
ٍ\end{array}$ & 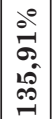 & 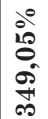 \\
\hline & Y'S!̣.xәұUI & $\begin{array}{l}\overrightarrow{0} \\
\dot{8} \\
\infty \\
\stackrel{2}{F}\end{array}$ & $\begin{array}{l}-\overline{0} \\
\dot{8} \\
\infty \\
\stackrel{9}{F}\end{array}$ & $\begin{array}{l}\vec{b} \\
\dot{0} \\
\infty \\
\stackrel{2}{F}\end{array}$ & 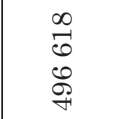 & $\begin{array}{l}10 \\
\text { O } \\
o \\
0 \\
10 \\
\text { N }\end{array}$ & $\begin{array}{l}8 \\
\varnothing \\
0 \\
0\end{array}$ & 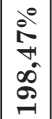 & 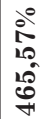 \\
\hline & !ฺยләиәり & $\begin{array}{l}\text { 尺े } \\
10 \\
0 \\
10 \\
10\end{array}$ & $\begin{array}{l}\text { I } \\
\text { N } \\
\text { से } \\
10\end{array}$ & $\begin{array}{l}\text { ㅇ. } \\
\text { 10 } \\
0 \\
10 \\
10\end{array}$ & 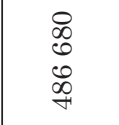 & $\begin{array}{l}10 \\
0 \\
0 \\
0 \\
0 \\
0\end{array}$ & 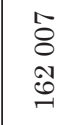 & \begin{tabular}{c}
$\stackrel{0}{0}$ \\
\multirow{3}{+}{} \\
10 \\
10 \\
$\stackrel{1}{1}$
\end{tabular} & 苟 \\
\hline & edoxn & $\begin{array}{l}\vec{\sigma} \\
\overrightarrow{-} \\
\infty \\
\vec{\sigma} \\
-1\end{array}$ & $\begin{array}{l}\vec{\sigma} \\
\overrightarrow{-} \\
\infty \\
\overrightarrow{0} \\
-\end{array}$ & $\begin{array}{l}\vec{\sigma} \\
\overrightarrow{-} \\
\infty \\
\overrightarrow{0} \\
\sigma \\
-1\end{array}$ & $\begin{array}{l}\vec{\sigma} \\
\overrightarrow{-} \\
\infty \\
\overrightarrow{0} \\
-1\end{array}$ & 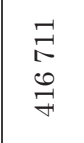 & 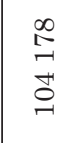 & 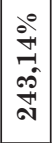 & 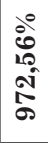 \\
\hline & 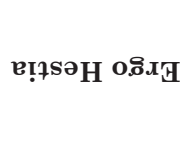 & 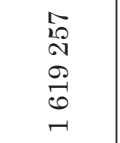 & 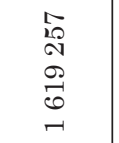 & 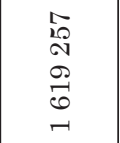 & 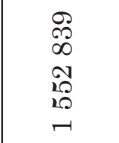 & 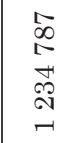 & $\begin{array}{l}10 \\
10 \\
10 \\
10 \\
10\end{array}$ & 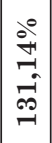 & 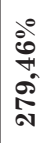 \\
\hline & esuəduo & $\begin{array}{l}\mathscr{8} \\
8 \\
\text { Oै } \\
\mathcal{H}\end{array}$ & $\begin{array}{l}\stackrel{2}{2} \\
\stackrel{0}{0} \\
\stackrel{\forall}{\forall}\end{array}$ & \begin{tabular}{l}
$\infty$ \\
8 \\
\multirow{2}{*}{} \\
\multirow{F}{*}{}
\end{tabular} & $\begin{array}{l}\stackrel{0}{2} \\
\stackrel{1}{0} \\
\stackrel{7}{\forall} \\
\forall\end{array}$ & $\begin{array}{l}N \\
\stackrel{N}{\rho} \\
\infty \\
\infty \\
\infty \\
\stackrel{N}{N}\end{array}$ & 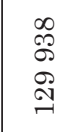 & 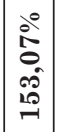 & $\begin{array}{c}\circ 0 \\
0 \\
0 \\
0 \\
0 \\
-1 \\
-10\end{array}$ \\
\hline & VXV & 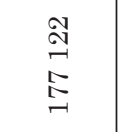 & 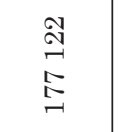 & 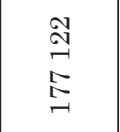 & 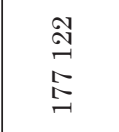 & $\begin{array}{l}-1 \\
8 \\
\circ \\
\stackrel{0}{0} \\
\stackrel{-1}{-1}\end{array}$ & $\begin{array}{l}\infty \\
\text { N } \\
i 0 \\
F \\
F\end{array}$ & 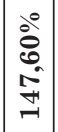 & 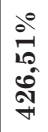 \\
\hline & $\mathrm{e} \Lambda ! \Lambda \mathrm{V}$ & 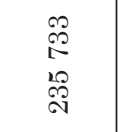 & 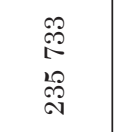 & 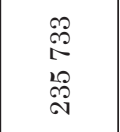 & $\begin{array}{l}\infty \\
\stackrel{\infty}{\circ} \\
\stackrel{0}{\circ} \\
\stackrel{\circ}{N}\end{array}$ & $\begin{array}{l}0 \\
\& \\
\infty \\
10 \\
\stackrel{N}{7}\end{array}$ & $\begin{array}{l}0 \\
0 \\
0 \\
0 \\
10\end{array}$ & $\begin{array}{c}0 \\
\infty \\
\infty \\
0 \\
0 \\
\infty \\
\infty \\
-1\end{array}$ & 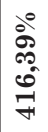 \\
\hline & zue!IIV & $\begin{array}{l}? \\
\qquad \\
\infty \\
0 \\
0 \\
-1\end{array}$ & $\begin{array}{l}? \\
0 \\
\infty \\
0 \\
0 \\
-1\end{array}$ & $\begin{array}{l}5 \\
6 \\
\infty \\
0 \\
0 \\
-1\end{array}$ & 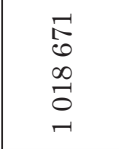 & 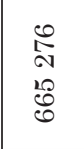 & 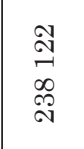 & 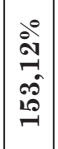 & 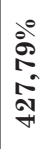 \\
\hline & & 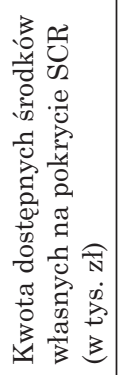 & 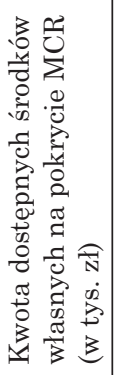 & 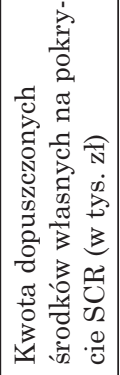 & 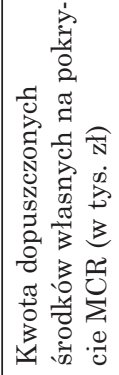 & 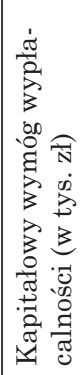 & 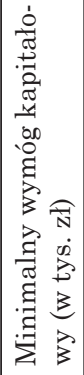 & 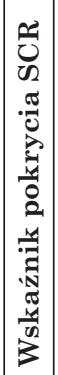 & 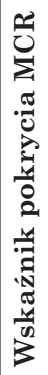 \\
\hline
\end{tabular}




\section{Analiza pokrycia wymogów kapitałowych środkami własnymi}

Ocena pokrycia wymogów kapitałowych środkami własnymi jest kluczowa kwestią w kontekście oceny wypłacalności danego zakładu ubezpieczeń. Dysponowanie wolnymi środkami sprawia, że działalność danego zakładu ubezpieczeń jest bezpieczniejsza, jednakże powoduje tym samym obniżenie wskaźników rentowności danego podmiotu. Zgodnie z wymogami ustawodawcy środki własne zakładu ubezpieczeń muszą być wyższe od kapitałowego wymogu wypłacalności. Zakłady ubezpieczeń mogą także w ramach swojej polityki zarządzania kapitałem narzucić własne wymogi dotyczące pokrycia wymogów kapitałowych środkami własnymi.

W 2016 r. zdecydowana większość środków własnych była zaliczana do najlepszej kategorii jakościowej. W efekcie wszystkie środki własne kontrolowane przez analizowane zakłady ubezpieczeń stanowiły środki własne dopuszczone do pokrycia kapitałowego wymogu wypłacalności. Wszystkie badane zakłady ubezpieczeń posiadały wymaganą kwotę dopuszczonych środków własnych na pokrycie kapitałowego wymogu wypłacalności i minimalnego wymogu kapitałowego (tabela 7). Najwyższy wskaźnik pokrycia kapitałowego wymogu wypłacalności środkami własnymi odnotowała Europa. Wskaźnik pokrycia kapitałowego wymogu wypłacalności tego zakładu ubezpieczeń wyniósł $243 \%$ i jako jedyny w badanej grupie zakładów ubezpieczeń przekroczył poziom 200\%. Wysoki poziom pokrycia kapitałowego wymogu wypłacalności zaobserwowano też w zakładach ubezpieczeń Aviva i Interrisk, gdzie wynosił on odpowiednio 198\% i 187\%. Stosunkowo niski stopień pokrycia kapitałowego wymogu wypłacalności środkami własnymi charakteryzował Ergo Hestię oraz Uniqę i nie przekroczył on tam poziomu 135\%. W 2016 r. jedynie zakład ubezpieczeń Ergo Hestia nie wykazał w swoim sprawozdaniu wskaźnika pokrycia minimalnego wymogu kapitałowego o wartości większej od 3. Relatywnie niski wskaźnik pokrycia minimalnego wymogu kapitałowego adekwatnymi środkami własnymi zaobserwowano w sprawozdaniach zakładu ubezpieczeń Generali oraz zakładu ubezpieczeń Compensa i w obu tych zakładach wskaźnik był zbliżony do wartości 300\%. Najwyższy poziom pokrycia dolnego wymogu kapitałowego odnotowano w zakładzie ubezpieczeń Europa i wyniósł on $972 \%$. Tak wysoki poziom pokrycia minimalnego wymogu kapitałowego może sugerować, że zakład ubezpieczeń posiada nadmiar środków własnych, które moga powodować obniżenie rentowność kapitałów własnych poprzez efekt dźwigni finansowej. We wszystkich pozostałych badanych zakładach ubezpieczeń wskaźnik pokrycia minimalnego wymogu kapitałowego nie przekroczył poziomu 500\%.

Analiza wskaźników pokrycia wymogów kapitałowych odpowiednimi środkami własnymi wskazuje, że wszystkie badane zakłady ubezpieczeń spełniaja normy wypłacalności określone przez ustawodawcę w ustawie o działalności ubezpieczeniowej i reasekuracyjnej. Taka sytuacja świadczy o tym, że w badanej grupie wszystkie zakłady ubezpieczeń charakteryzowały się dobrą i bardzo dobrą sytuacją finansowa. Ocena wypłacalności zakładów ubezpieczeń dokonana na podstawie regulacji prawnych wdrożonych dyrektywą Solvency II pozwala na stwierdzenie, że z ufnością 99,5\% żaden z badanych zakładów ubez- 
pieczeń nie będzie zagrożony niewypłacalnością i w okresie 12 miesięcy będzie w stanie kontynuować swoją działalność w niezmienionym istotnie zakresie bez postawienia spółki w stan likwidacji.

\section{PODSUMOWANIE}

System bazujący na pokryciu marginesu wypłacalności i kapitału gwarancyjnego odpowiednimi środkami własnymi przez wiele lat determinował działalność zakładów ubezpieczeń. Wraz z rozwojem rynku ubezpieczeniowego i identyfikacją nowych rodzajów ryzyka w obszarze działalności zakładów ubezpieczeń system Solvency I okazał się nieadekwatny i nie gwarantował pożądanego poziomu realności ochrony ubezpieczeniowej. Dyrektywa Solvency II stała się katalizatorem przełomowych zmian na europejskim rynku ubezpieczeniowym. Koncepcja kapitału ważonego ryzykiem przy wyznaczaniu wymogów kapitałowych nie jest nową koncepcją stosowaną wśród instytucji finansowych. Podobne rozwiązania stosują ubezpieczyciele w Stanach Zjednoczonych oraz europejski sektor bankowy. System Solvency II wpisuje się więc w trend uwzględniania całkowitego ryzyka działalności przy konstruowaniu standardów wypłacalności.

Regulacje dotyczące działalności zakładów ubezpieczeń do czasów wprowadzenia dyrektywy Solvency II do polskiego systemu prawnego nie uwzględniały całkowitego ryzyka prowadzanej działalności ubezpieczeniowych oraz nowych metod zarządzania ryzykiem. Od 2016 r. zakłady ubezpieczeń obliczają swoje wymogi kapitałowe na podstawie indywidualnych profili ryzyka, uwzględniając w ten sposób specyfikę działalności danego ubezpieczyciela. Kalibrowanie wymogów kapitałowych na podstawie profili ryzyka ma sprawić, że działalność ubezpieczycieli będzie charakteryzowała się większym stopniem bezpieczeństwa, przez co zwiększy się realność ochrony ubezpieczeniowej. System Solvency II skłania zakłady ubezpieczeń do pomiaru ryzyka i efektywnego zarządzania nim m.in. przez wykorzystanie efektów dywersyfikacji. Zakłady ubezpieczeń moga także dostosować jakość środków własnych do wymogów kapitałowych, przez co mogą efektywniej zarządzać kapitałami. Nowy system wypłacalności zachęca zakłady ubezpieczeń do korzystania z alternatywnych, względem reasekuracji, form transferu ryzyka.

Dyrektywa Solvency II wprowadziła regulacje dotyczące sprawozdawczości zakładów ubezpieczeń, dzięki czemu działalność tych instytucji stała się bardziej transparentna. Na podstawie analizy tych sprawozdań można wnioskować m.in. o tym, czy dany zakład ubezpieczeń spełnia normy kapitałowe narzucone przez ustawodawcę, w jaki sposób zarządza on swoimi kapitałami oraz jakie kategorie ryzyka identyfikuje w toku swojej działalności. Podjęta w artykule analiza działalności wybranej grupy zakładów ubezpieczeń pozwoliła porównać sytuację finansową tych zakładów, przez badanie adekwatności kapitałowej, porównanie profili ryzyka czy wysokości i jakości posiadanych środków własnych. Informacje ujawniane w sprawozdaniach o wypłacalności i kondycji finansowej zakładów ubezpieczeń mogą być użyteczne zarówno dla 
konsumenta ochrony ubezpieczeniowej, jak i dla wszystkich innych zainteresowanych osób, w tym także konkurencji.

Należy zauważyć, że system Solvency II generuje także zagrożenia dla sektora ubezpieczeniowego. Pomimo zwiększenia bezpieczeństwa działalności ubezpieczeniowej podkreśla się, że wdrożenie nowego systemu wypłacalności może przyczynić się do ograniczenia zaangażowania zakładów ubezpieczeń w działalność kapitałochłonną. Zakłady ubezpieczeń, dążąc do zwiększenia rentowności kapitału własnego, mogą unikać produktów ubezpieczeniowych nadmiernie eksponujących na ryzyko. Do takich produktów należy zaliczyć w szczególności ubezpieczenia katastroficzne i środowiskowe oraz długoterminowe ubezpieczenia na życie i niektóre ubezpieczenia odpowiedzialności cywilnej. Wdrożenie nowego systemu wypłacalności stanowi też wyzwanie dla zarządzania portfelem lokat oraz rezerw techniczno-ubezpieczeniowych.

dr hab. Piotr Manikowski

Profesor Uniwersytetu Ekonomicznego w Poznaniu

piotr.manikowski@ue.poznan.pl

mgr Rafat Matuła

Uniwersytet Ekonomiczny w Poznaniu

rafal.matula@ue.poznan.pl

\section{INSURERS' SOLVENCY ANALYSIS IN SOLVENCY II SYSTEM ON THE EXAMPLE OF SELECTED COMPANIES}

$$
\text { Summary }
$$

\footnotetext{
Solvency is one of the key factors in the functioning of any enterprise, including in particular insurance companies. Owing to the nature of the business, insurers' solvency has long been regulated in detail not only by national laws, but also by European law. The insurance market has undergone a major change recently. So far Solvency I rules - already well known by insurers and generally not too complicated, have been now replaced by Solvency II, which is a huge challenge for the insurance market. The main aim of the article is to analyse the solvency of a selected group of ten Polish insurance companies, according to the solutions adopted in the new legal system governed by the Solvency II Directive. The paper also deals with the basic issues related to the concept of the solvency of the insurance companies, regulating these issues in the legislation, and general characteristics of the requirements of insurance companies in the Solvency II regime. This has been the first work that refers to the financial data of Polish insurers disclosed for the first time in May 2017 in completely new Solvency and Financial Condition Reports (SFCR).
} 